\title{
Redescription of Monorcholepis dujardini (Krabbe, 1869) and M. passerellae (Webster, 1952) (Cestoda: Cyclophyllidea: Aploparaksidae) in passerine birds from the Holarctic Region
}

\author{
Svetlana Bondarenko and Jurijus Komisarovas
}

Institute of Ecology, Vilnius University, Akademijos 2, LT-08412 Vilnius-21, Lithuania

Key words: Cestoda, Cyclophyllidea, Aploparaksidae, Monorcholepis, Passeriformes, Holarctic

\begin{abstract}
Two species of avian tapeworms, Monorcholepis dujardini (Krabbe, 1869) and M. passerellae (Webster, 1952), of the cyclophyllidean family Aploparaksidae Mayhew, 1925 (earlier included in the Hymenolepididae) are redescribed. Relative to congeners, the morphology of the strobila of both species shows strong similarities including a unique form of the cirrus. Separation of these species, however, can be based on the number (40-53 and 25-31, respectively) and size (18-25 $\mu \mathrm{m}$ and $14-18 \mu \mathrm{m})$ of the rostellar hooks, although their shape in specimens of both species varies considerably. We examined specimens of Monorcholepis dujardini in Turdus iliacus L., T. philomelos Brehm and T. merula L. from the Curonian Spit (Baltic Sea, Russia), T. naumanni Temminck from Chukotka, Motacilla alba L. from the Kuril Islands (Russia) and Passerella iliaca iliaca (Merrem) from Alaska (USA). Specimens in T. iliacus from the collection of O. Fuhrmann (Natural History Museum, Geneva, Switzerland) were re-studied. The type material (holotype and paratypes) designated as M. dujardini neoarctica (Webster, 1955) in Ixoreus naevius naevius (Gmelin) from Douglas Island, USA was re-examined and validity of this subspecies was rejected. A redescription of M. passerellae (Webster, 1952) was based on material in P. iliaca iliaca from Wisconsin (type specimen), and Point Barrow, Alaska, and on the one specimen recorded for the first time, in Turdus iliacus from the Palaearctic (Curonian Spit). Species of the genus Monorcholepis Oshmarin, 1963 and subgenus Aploparaksis (Tanureria) Spassky et Yurpalova, 1968 are characterized by similar topography of the gonads. These generic taxa and the interrelationships of constituent species are discussed.
\end{abstract}

The genus Monorcholepis Oshmarin, 1963 (Cestoda: Cyclophyllidea, Aploparaksidae) with the type species M. dujardini (Krabbe, 1869) includes parasites of Passeriformes. Most of them were originally described as members of Aploparaksis Clerc, 1903. Clerc (1903) placed into this genus cestodes with one testis per proglottis, including A. dujardini (Krabbe, 1869). The morphological characters of $A$. dujardini, a parasite of passeriform birds, and Aploparaksis spp., parasites of charadriiform birds, corresponded well, with the only one exception being the number of the rostellar hooks. The rostellum of Aploparaksis spp. is armed with 10 hooks, whereas the number of hooks of the A. dujardini is much higher (40-46, according to Krabbe 1869). Since establishment of the genus Aploparaksis, additional species with more than 10 rostellar hooks have been described primarily in passerine birds from the Nearctic: Aploparaksis passerellae Webster, 1952 in Passerella iliaca iliaca (Merrem), A. dujardini neoarcticus Webster, 1955 in Ixoreus naevius naevius (Gmelin), A. turdi Williamson et Rausch, 1965 in Turdus migratorius $\mathrm{L}$. and Ixoreus naevius, and A. picae Todd, 1967 in Pica pica hudsonia (Sabine). In addition, Monorcholepis sobolevi Tsimbalyuk, Andronova et Kulikov in Spasskaya, 1966 was described based on specimens in five species of passerine birds from Karaginskiy and Komandorskiy Islands (Russia, Far East). Tsimbalyuk, Andronova and Kulikov (1968) re- corded M. sobolevi as an obligate parasite of Calcarius lapponica $(\mathrm{L}$.$) .$

The diagnosis of Monorcholepis was based on the characters of $M$. dujardini recorded in thrushes and Monorcholepis sp. in Vulpes vulpes from the Primorskiy Kray, Russia (Oshmarin 1963). This author did not address the taxonomic status of North-American species of Aploparaksis with more than 10 rostellar hooks. Spassky and Freze (1961) and Spassky (1963) excluded A. dujardini from Aploparaksis and placed it in Monorcholepis referring to "Oshmarin (1961, in print)"; i.e., before the original generic diagnosis was published by Oshmarin (1963), bringing confusion in the date for erection of the genus. Later, A. dujardini neoarctica, $A$. passerellae and $A$. turdi were transferred into $\mathrm{Mo}$ norcholepis (Spassky 1963, Spassky and Spasskaya 1972). Concurrently, M. dujardini neoarctica was considered as a taxon of uncertain status because of incomplete original description (Spassky and Spasskaya 1972), although Williamson and Rausch (1965) considered this subspecies as a morphological variation of $A$. dujardini.

In total, five species and one subspecies of Aploparaksis correspond well to the diagnosis of $\mathrm{Mo}$ norcholepis. Among them only M. turdi clearly differs in the shape and length of the rostellar hooks, which are characterized by a long handle, and in the morphology of the copulatory apparatus (long and thick cylindrical 
cirrus). With the exception of $M$. dujardini, all other species of the genus Monorcholepis are known only from the original descriptions.

Recently, Bondarenko and Kontrimavichus (2006) have found $M$. sobolevi, a species characterized by 20 rostellar hooks (16 hooks reported in the original description), as a typical parasite of passerine birds from Chukotka. In the same locality they found an additional species of this genus, $M$. atrashkevichi Bondarenko et Kontrimavichus, 2006, which is very similar to $M$. sobolevi, but distinguished from it by the number of rostellar hooks (40). It is difficult to separate these species on the basis of morphology, as both are characterized by a relatively short, cylindrical to conical cirrus and similar shape of the rostellar hooks. A parallel situation is observed with two other morphologically similar species, M. dujardini and $M$. passerellae, which are characterized by uniformity in the structure of the cirrus.

The aim of the present study is to redescribe $M$. $d u$ jardini on the basis of specimens from Europe, Asia and North America, and M. passerellae, based on of the type specimen and new findings from Alaska and the Curonian Spit (Baltic Sea, Russia).

\section{MATERIALS AND METHODS}

\section{We examined the following specimens:}

Monorcholepis dujardini, Collection of the Natural History Museum, Geneva (MHNG), Collection Neuchâtel (O. Fuhrmann - J. Baer), No. 62/1-13, in T. iliacus (syn. T. musicus), originally labeled as a lot received from the Vienna Museum, number 19 (series of transverse and longitudinal sections of different part of strobila; scolex is lacking).

Monorcholepis dujardini neoarctica (Webster, 1955), U.S. National Parasite Collection (USNPC), holotype and paratypes in Ixoreus naevius naevius. USNPC 46648.02 - slide containing the holotype ('type' - immature specimen) and five paratypes (scoleces and neck only); the holotype is designated by a circle on the coverslip. USNPC 46648.01 - remnants of material from the type host and locality preserved in ethanol, containing one fragment of a premature specimen and 5 scoleces; the latter were studied in polyvinyl alcohol for detailed examination of their rostellar hooks. According to Webster (1955), the site, date, locality, and collector are unknown; however, the following information is included in the USNPC catalogue: USA, Alaska, Douglas Island, June 1949, collector Williams, R.B., identifier Webster, J.D.

Monorcholepis dujardini, 12 specimens in Turdus iliacus from the Curonian Spit, Baltic Sea, Kaliningrad Region, Russia, collected by J. Komisarovas, 9-12 October 2004; one specimen in $T$. merula from the Curonian Spit, collected by $\mathrm{J}$. Komisarovas, 20 October 2003; two specimens in T. philomelos from the Curonian Spit, collected by J. Komisarovas, 11 October 2005. Materials from the Curonian Spit are held in the collection of J. Komisarovas, except for one specimen which is deposited in the collection of the MHNG, INVE 47854 (C126/84).
Monorcholepis dujardini in Motacilla alba from Paramushir Island, Far East Russia (the vicinity of the city North Kuril'sk, 27 July 1965); one slide which was kindly provided for our investigation by Prof. O.I. Belogurov, Far East State University, Vladivostok, Russia; held in the collection of S.K. Bondarenko.

Monorcholepis dujardini, two specimens in one Turdus naumanni from West Chukotka, collected by S. Bondarenko, 9 July 1979; held in collection of S.K. Bondarenko.

Monorcholepis spp., 4 unidentified specimens and fragments in one Passerella iliaca iliaca from Point Barrow, Alaska on 29 May 1968 from the collection of Dr. R.L. Rausch (field number DWN B-14), which he kindly provided for our investigation; held in collection of S.K. Bondarenko.

Monorcholepis passerellae (Webster, 1952), USNPC 37365, holotype and paratypes in fox sparrow, Passerella iliaca iliaca from Wisconsin, USA.

Monorcholepis passerellae, one specimen in T. iliacus, collected by J. Komisarovas on the Curonian Spit, 12 October 2004; deposited in the collection of the MHNG, INVE 47855 (C126/85).

The fixed tapeworms were stained with Ehrlich's haematoxylin, dehydrated in an ascending alcohol series, cleared in clove oil and mounted in Canada balsam. The details of the morphology of the hooks, cirri and embryophores were also studied in specimens mounted in polyvinyl alcohol and in resin using the method of Steedmann (1958). Four scoleces and one fragment of the paratypes of $M$. dujardini neoarctica were mounted in polyvinyl alcohol because the available whole Canada-balsam mount did not allow exact examination. The measurements are given in micrometres $(\mu \mathrm{m})$ unless otherwise stated. The descriptions and redescriptions are given with our own illustrations with the exception of hooks from the type specimens of $M$. dujardini, which were redrawn from the original description as presented by Krabbe (1869).

\section{RESULTS}

Monorcholepis dujardini (Krabbe, 1869) Oshmarin, 1963

Syns.: Taenia dujardini Krabbe, 1869; Monorchis dujardini (Krabbe, 1869) Clerc, 1902; Aploparaksis dujardini (Krabbe, 1869) Clerc, 1903; Haploparaksis dujardini (Krabbe, 1869) Yamaguti, 1935; Aploparaksis dujardini neoarctica Webster, 1955

Redescription. Based on a series of transverse and longitudinal sections of different parts of strobila originally examined by O. Fuhrmann in MHNG (Figs. 1-3).

Proglottides 22-40 × 190-860. Ventral osmoregulatory canals 33 wide, with anastomosis in each proglottis; dorsal canals about 3 wide. Scolex and rostellar hooks not seen. Male genital system dorsal, consisting of single testis, vas deferens, cirrus-sac and armed cirrus. Testis $53-73 \times 36-46$ situated in aporal part of proglottis, near to lateral osmoregulatory canals. Cirrussac 200-207 long and 29-31 wide, may attain aporal osmoregulatory canals. External seminal vesicle elongate, $92 \times 26$, overlapping cirrus-sac dorsally. Internal 


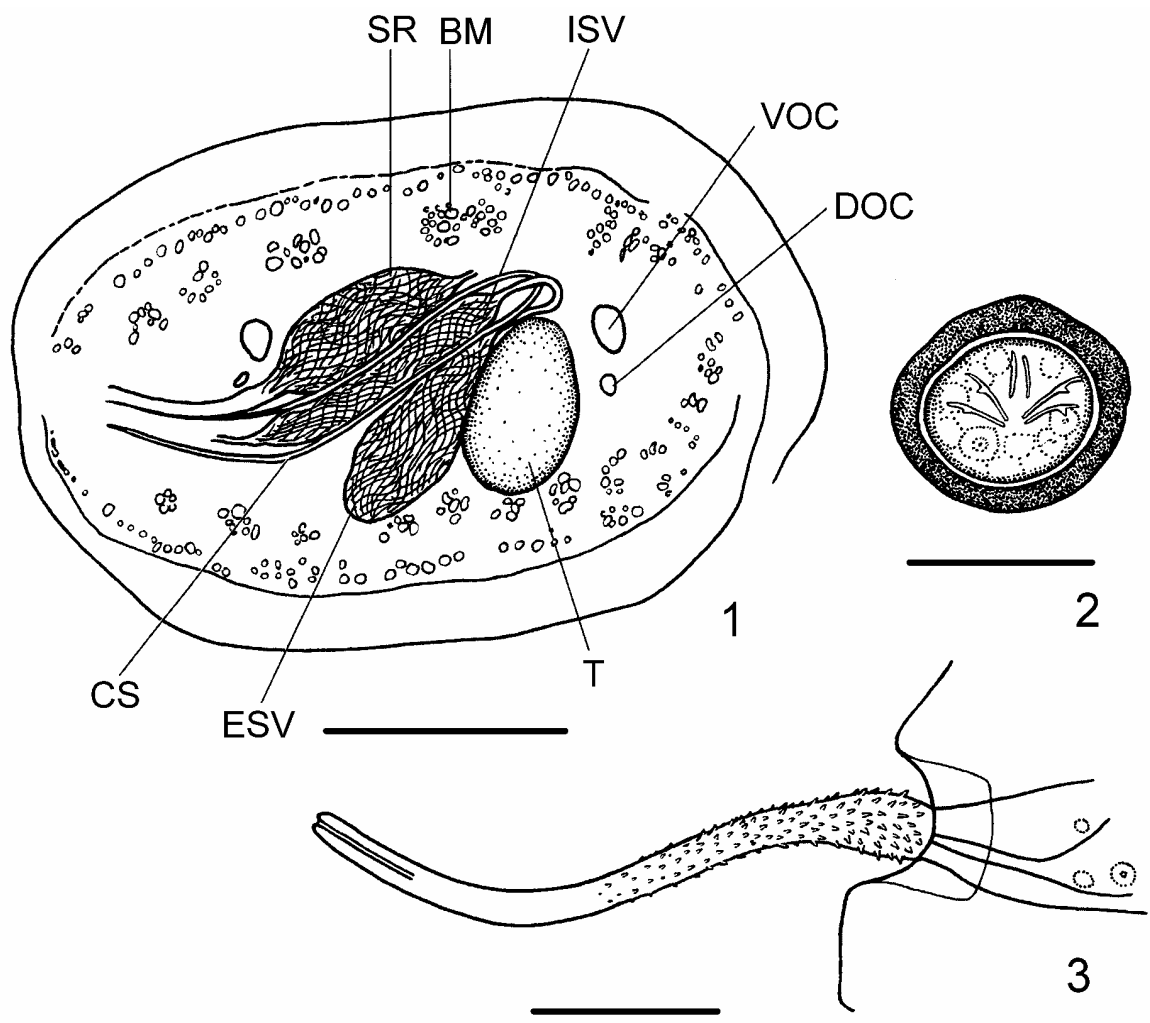

Figs. 1-3. Monorcholepis dujardini (Krabbe, 1869) drawn from Fuhrmann's (1895) specimens (MHNG, slides 62/2, 6). Fig. 1. Transverse section of the proglottis showing the position of longitudinal muscles of the strobila, male organs and seminal receptacle. Abbreviations: BM - bundle of muscles; CS - cirrus-sac; DOC - dorsal osmoregulatory canal; ESV - external seminal vesicle; ISV - internal seminal vesicle; T - testis; SR - seminal receptacle; VOC - ventral osmoregulatory canal. Fig. 2. Embryophore and oncosphere (median pair of embryonal hooks are shorter than lateral pairs due to retraction). Fig. 3. Cirrus. Scale bars: Fig. $1=100 \mu \mathrm{m}$; Figs. 2, $3=20 \mu \mathrm{m}$.

seminal vesicle 132 long, occupies $2 / 3$ of cirrus-sac length. Evaginated cirrus 67 long, distinctive shape; basal part of cirrus dilated ( 6 in diameter), then diameter of cirrus narrows to 4 and again expands, forming median fusiform part with maximal diameter 5; diameter of distal part 3. Proximal part of cirrus armed with small spines; spines differ in size. Largest spines cover basal swelling; distinctly smaller spines cover fusiform part; distal part of cirrus smooth. Female genital organs situated along transverse axis of proglottis. Part of ovary (observed in transverse sections) situated in centre of proglottis, ventral to male system. Vitellarium antiporal to ovary. Seminal receptacle elongate to oval, $89 \times 40$, ventral to cirrus-sac. Vagina tubular, 60 long. Gravid proglottides almost entirely filled with sac-shaped uterus. Embryophore 18-22 × 20-26, with thick (thickness 3-4) smooth walls; oncosphere 14 long and 16-18 wide; embryonic hooks 10-11 long.

- Description of the specimen in Turdus philomelos from the Curonian Spit

Figs. 4-8

Strobila $67 \mathrm{~mm}$ long, with a maximum width of 930 . Scolex $246 \times 218$. Suckers rounded, 73-82 in diameter. Rostellum rounded, 102 in diameter. Rostellar sheath $272 \times 136$. Rostellar hooks 40 in number, situated in single row. Hooks with blade about as long as guard. Length of hooks 17.5-18 (blade 8.3-10, base 17.5-18, guard 10-11.6). Genital pores unilateral, dextral; genital ducts dorsal to longitudinal osmoregulatory canals. Ventral osmoregulatory canals 20-33 wide, with rare anastomoses, dorsal osmoregulatory canals 4 wide. Male genital system with single testis, $102-110 \times 61-$ 65, antiporal. Cirrus-sac, 190-210 × 20-23, reaching midline of proglottis or passing it. Internal seminal vesicle occupies $2 / 3$ of cirrus-sac. External seminal vesicle large, ovoid, near middle of proglottides opposite antiporal region of cirrus-sac or overlying its dorsal surface. Evaginated cirrus 103-110 long. At basal part, cirrus with dilatation, 10 in diameter, then a little slender part with diameter 5.6-7 and fusiform median part with 7.4 8 in diameter. Proximal part of cirrus covered with fine spines. Female system with trilobed ovary. Vitellarium compact, oval, 49-65 × 40-49, antiporal to ovarium. Vagina tubular. Seminal receptacle oval, $82-90 \times 61-$ 65 , in poral half of median field or in middle. Short duct leading to triangular-shaped Mehlis' gland, 60-62 in diameter. Gravid uterus sacciform, occupies almost entire proglottis. Eggs numerous, rounded, 53-54 in diameter. Embryophore 25-30 in diameter; wall smooth, 


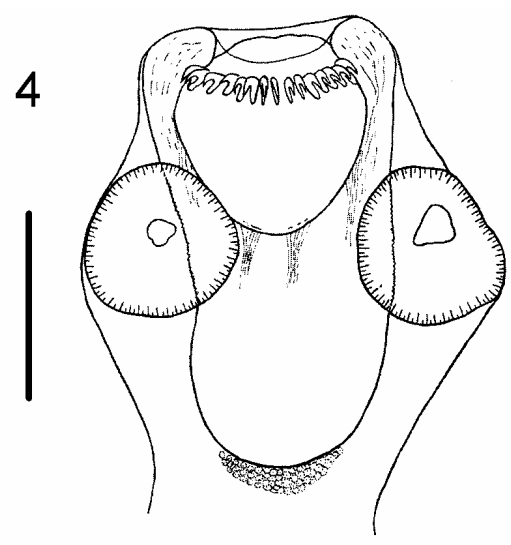

5
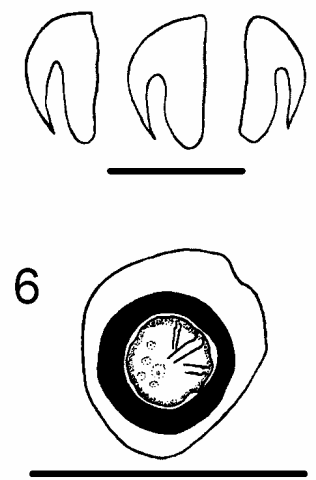

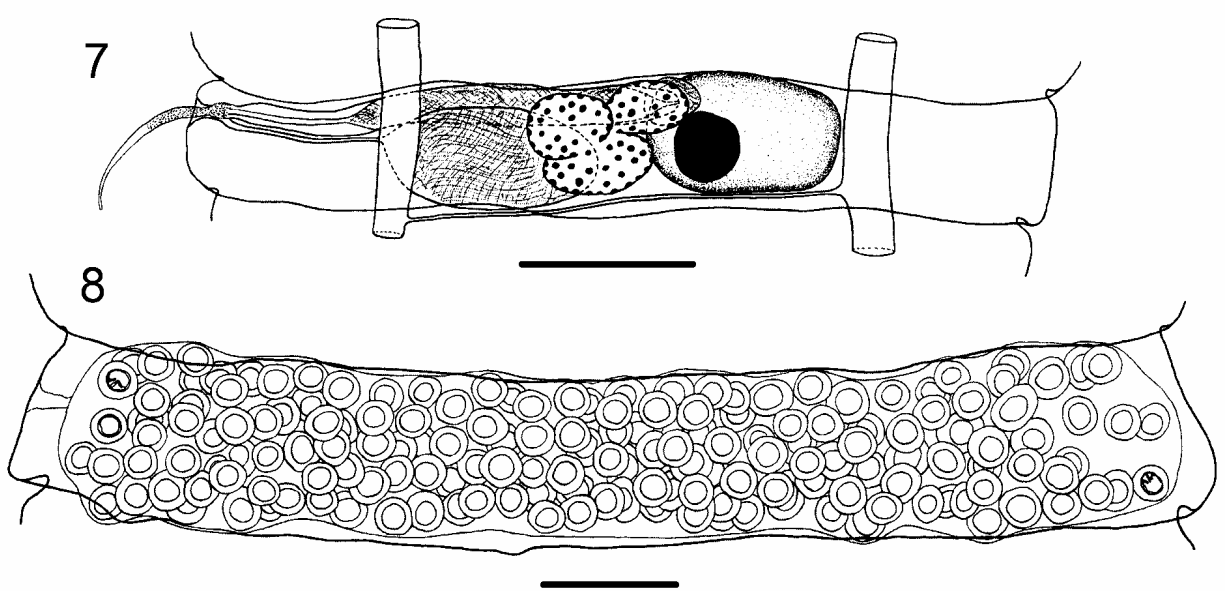

Figs. 4-8. Monorcholepis dujardini in Turdus philomelos (present study, Curonian Spit) (MHNG INVE 47854, C126/84). Fig. 4. Scolex. Fig. 5. Hooks. Fig. 6. Egg. Fig. 7. Mature proglottis. Fig. 8. Gravid proglottis. Scale bars: Figs. 4, 7, $8=100 \mu$ m; Fig. 6 $=50 \mu \mathrm{m}$; Fig. $5=20 \mu \mathrm{m}$.

4-5 in thickness, without polar thickenings. Oncosphere 15-17 in diameter, embryonic hooks of central and lateral pairs identical in shape and length, 10-11 long.

Summarized measurements of specimens in Turdus spp. collected from Curonian Spit are given in Table 1. The morphology of the hooks of specimens in T. iliacus and $T$. merula from the same locality is represented in Figs. 9-16.

- Description of specimens in Passerella iliaca from Point Barrow, Alaska (2 of 4 specimens collected by R.L. Rausch)

Figs. 17-19

Strobila $35 \times 0.70-0.76 \mathrm{~mm}$. Rostellum rounded, armed with 50 and 51 hooks, blade of same length or little longer than guard. Length of hooks, measured from intact rostellum: on superior surface of a slide 21.5-23 in length, whereas 18 in length (blade 11.6-13, base 17-20, guard 8-9) when measured on bottom surface. Male system with single testis, $62-70 \times 106-119$. Cirrus-sac 193-291 × 26-29 (cavity diameter 21-25), reaching midline of proglottis or passing it. Internal seminal vesicle $120-160 \times 21-24$. Evaginated cirrus 103-106 long; basal part of cirrus with dilatation, 8-10 in diameter, then a little slender part with diameter 5 ,
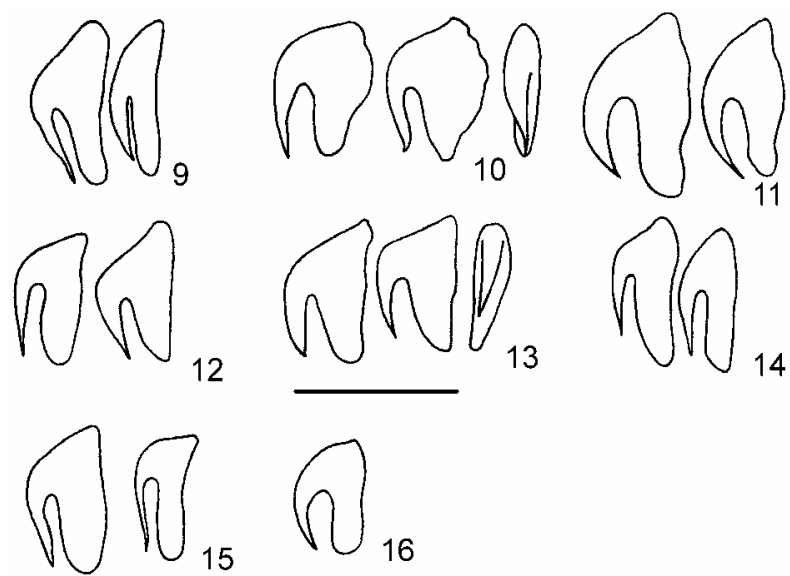

16

Figs. 9-16. Rostellar hooks of Monorcholepis dujardini in different thrushes in Curonian Spit (present study). Figs. 9-15. Hooks of specimens in Turdus iliacus. Fig. 16. Hook of specimen from Turdus merula. Scale bar $=20 \mu \mathrm{m}$.

and fusiform median part up to 8 (with spines). Proximal part of cirrus covered with small spines. Spines on basal and median part slightly larger than those on slender part. Distal part of cirrus 62 long, unarmed. Female 

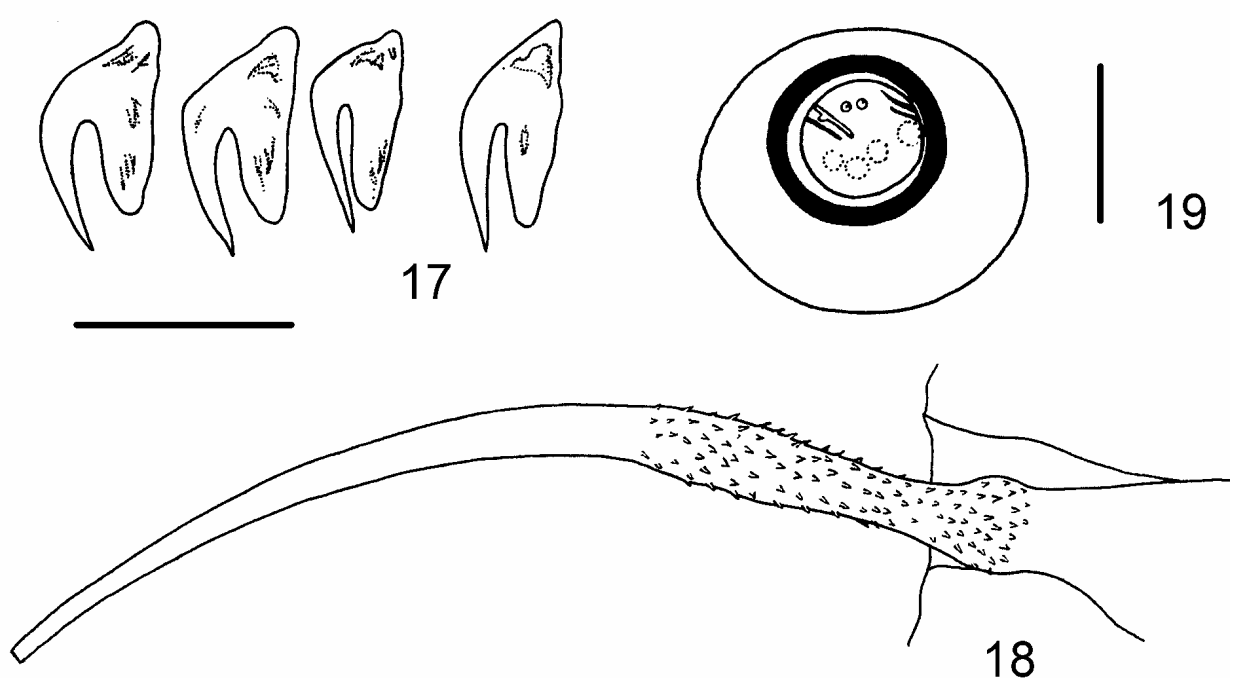

Figs. 17-19. Monorcholepis dujardini in Passerella iliaca from Point Barrow, Alaska. Fig. 17. Hooks. Fig. 18. Cirrus. Fig. 19. Egg. Scale bars: Figs. 17, $18=20 \mu \mathrm{m}$; Figs. $19=30 \mu \mathrm{m}$.

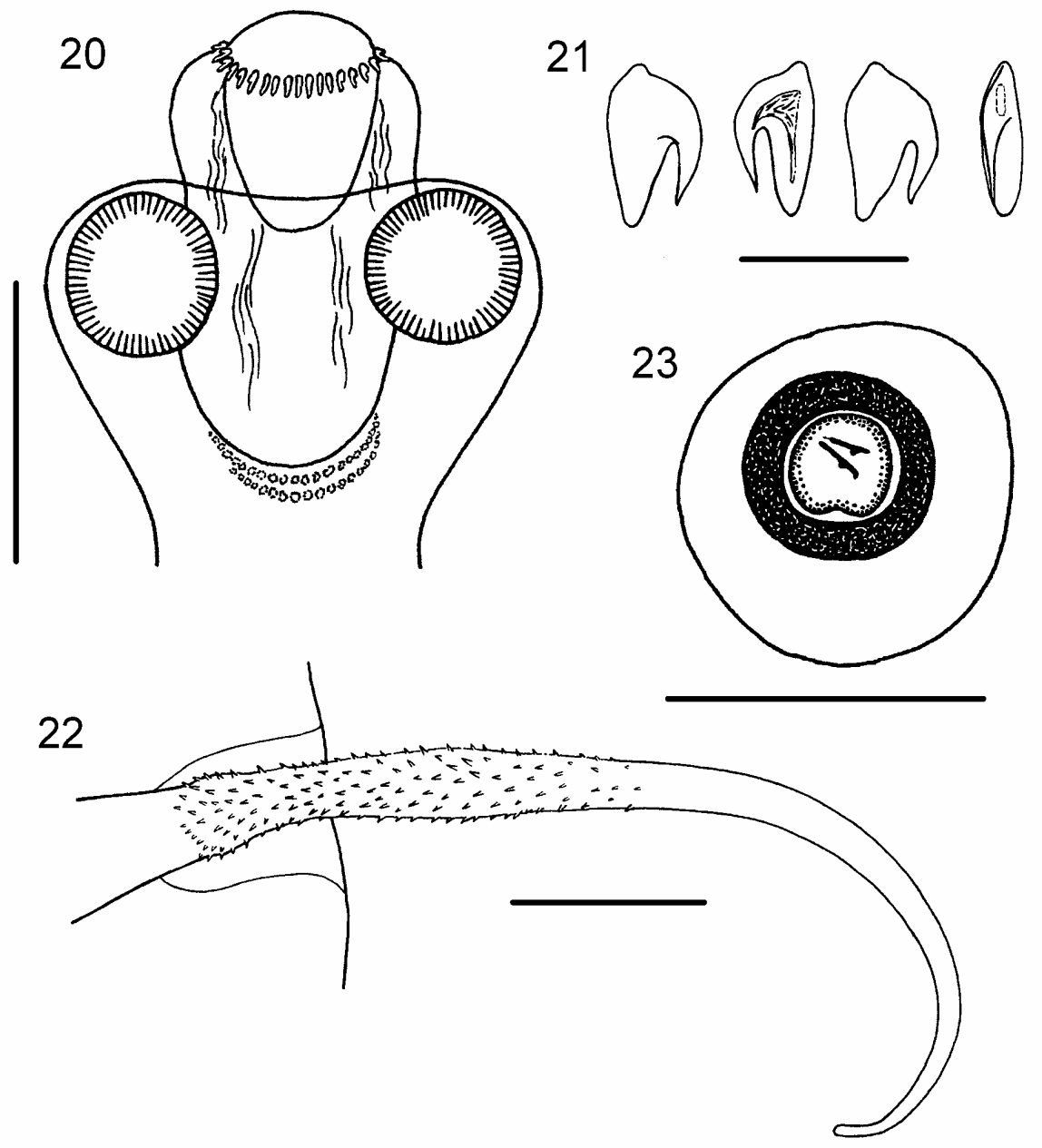

Figs. 20-23. Monorcholepis dujardini in Turdus naumanni from Chukotka and Motacilla alba from Paramushir Island (Kuril Islands). Fig. 20. Scolex. Fig. 21. Hooks. Fig. 22. Cirrus. Fig. 23. Egg. Scale bars: Fig. $20=100 \mu$ m; Figs. $21,22=20 \mu \mathrm{m}$; Fig. $23=50 \mu \mathrm{m}$. 
Table 1. Metrical and meristic characters of Monorcholepis dujardini (Krabbe, 1869) by various authors.

\begin{tabular}{|c|c|c|c|c|c|c|}
\hline $\begin{array}{l}\text { Host } \\
\text { Locality } \\
\mathrm{n} \\
\text { Source }\end{array}$ & $\begin{array}{l}\text { Turdus iliacus } \\
? \\
\text { Sections only } \\
\text { Fuhrmann } 1895\end{array}$ & $\begin{array}{l}\text { Turdus naumanni } \\
\text { Japan } \\
\text { No data } \\
\text { Yamaguti } 1935\end{array}$ & $\begin{array}{l}\text { Turdus obscurus } \\
\text { Primorskiy Kray } \\
\text { No data } \\
\text { Oshmarin } 1963\end{array}$ & $\begin{array}{l}\text { Passerela iliaca } \\
\text { Alaska } \\
2 \\
\text { Present study }\end{array}$ & $\begin{array}{l}\text { Ixoreus naevius } \\
\text { Alaska } \\
7 \\
\text { Present study*** }\end{array}$ & $\begin{array}{l}\text { Turdus spp. } \\
\text { Curonian Spit } \\
15 \\
\text { Present study }\end{array}$ \\
\hline $\begin{array}{l}\text { Body: } \\
\text { length }(\mathrm{mm}) \\
\text { width }(\mathrm{mm})\end{array}$ & $\begin{array}{c}25 \\
0.86\end{array}$ & $\begin{array}{c}11 \\
0.80\end{array}$ & $\begin{array}{c}8.7-20 \\
0.80-0.81\end{array}$ & $\begin{array}{c}35 \\
0.70-0.76\end{array}$ & $\begin{array}{l}3.65 \\
0.25\end{array}$ & $\begin{array}{c}7-70 \\
0.40-0.93\end{array}$ \\
\hline Scolex: width & about $300^{*}$ & & $280-385$ & - & $266 \times 262$ & $230-350$ \\
\hline Rostellum: size & 125 & $75-90$ & - & & & $82-110 \times 78-135$ \\
\hline Rostellar sheath: size & - & $160 \times 150$ & - & & $246 \times 160$ & $189-260 \times 130-220$ \\
\hline Rostellar hooks: number & 46 & $46 ?$ & 44 & $50-51$ & $43-53$ & $40-52$ \\
\hline $\begin{array}{l}\text { Hook: } \\
\text { total length } \\
\text { length of blade } \\
\text { length of base } \\
\text { guard }\end{array}$ & $\begin{array}{c}16-18 \\
- \\
- \\
-\end{array}$ & $\begin{array}{c}16-18 \\
- \\
-\end{array}$ & $\begin{array}{l}20 \\
- \\
- \\
-\end{array}$ & $\begin{array}{c}18-24.8 \\
11.6-14 \\
17-20 \\
8-9\end{array}$ & $\begin{array}{c}18 \\
9-10 \\
14.9-16.6 \\
5-7.4\end{array}$ & $\begin{array}{c}17-18.2 \\
6.6-8.3 \\
17-18.2 \\
8-11.6\end{array}$ \\
\hline $\begin{array}{l}\text { Cirrus-sac: size } \\
\text { Cirrus: shape }\end{array}$ & $\begin{array}{c}200-207 \times 29-31^{* *} \\
\text { spindle-shaped } * *\end{array}$ & $\begin{array}{c}120-250 \times 20-30 \\
-\end{array}$ & $\begin{array}{c}260-280 \times 18-25 \\
-\end{array}$ & $\begin{array}{c}193-291 \times 26-29 \\
\text { spindle-shaped }\end{array}$ & $\begin{array}{c}123-213 \times 18-21 \\
\text { spindle-shaped }\end{array}$ & $\begin{array}{c}164-250 \times 16-29 \\
\text { spindle-shaped }\end{array}$ \\
\hline $\begin{array}{l}\text { Cirrus: } \\
\text { total length } \\
\text { base width } \\
\text { constriction width } \\
\text { median part width }\end{array}$ & $\begin{array}{c}67 * * \\
6.4 * * \\
4 * * \\
5 * *\end{array}$ & $\begin{array}{l}120 \\
- \\
- \\
-\end{array}$ & $\begin{array}{l}- \\
- \\
- \\
-\end{array}$ & $\begin{array}{c}103-106 \\
8-10 \\
5 \\
8\end{array}$ & $\begin{array}{c}107-109 \\
8 \\
6.6 \\
10\end{array}$ & $\begin{array}{c}94-111 \\
10 \\
5.6-7 \\
7.4-8.3\end{array}$ \\
\hline Vitellarium: position & antiporal & antiporal & antiporal & antiporal & antiporal & antiporal \\
\hline $\begin{array}{l}\text { Embryophore: } \\
\text { diameter } \\
\text { wall thickness } \\
\text { oncosphere diameter } \\
\text { embryonic hook length }\end{array}$ & $\begin{array}{c}18 \times 20^{* *} \\
14 \times 14 ; 16 \times 14^{* *} \\
10-11^{* *}\end{array}$ & $\begin{array}{c}27-33 \times 26-30 \\
3 \text { or more } \\
18-27 \times 18-22 \\
10-11\end{array}$ & $16 \times 16$ & $\begin{array}{c}33-37 \times 29-33 \\
4 \\
21-22 \times 24-25 \\
12-13\end{array}$ & $\begin{array}{l}- \\
- \\
- \\
-\end{array}$ & $\begin{array}{l}25-30 \\
5 \\
15-17 \\
10-11\end{array}$ \\
\hline
\end{tabular}

*Measurement with scale bar on Fuhrmann's (1895) figure; **present study of Fuhrmann's (1895) material; ***type and paratypes of M. dujardini neoarctica; measurements in $\mu \mathrm{m}$ unless otherwise stated. 
gonads poorly delineated. Uterus fills most space of each proglottis. Gravid eggs $41-55$ in diameter. Embryophore $33-37 \times 29-33$, wall smooth, 4 in thickness, without polar thickenings. Oncosphere $21-22 \times 24-25$, closely adjoins to walls of embryophore; when free of embryophore, $25 \times 29$. Embryonic hooks $12-13$ long.

- Description of the specimens in Turdus naumanni from Chukotka and Motacilla alba from Paramushir Island

Figs. 20-23

Mature specimens 11-20 mm long and $0.8 \mathrm{~mm}$ maximum width at level of gravid proglottides. Scolex 330 in diameter. Suckers 100 in diameter. Rostellum $150 \times$ 120. Rostellar sheath $340 \times 175$. Rostellar hooks 46 (possible 48) with very short handle; blade short but pointed, shorter than guard. Length of hooks 17-18 (length of blade $6.6-8$, length of base 17-18, length of guard 8-10; width of hook in profile 10 , width of base in full face 5). In male system, cirrus-sac $168 \times 18$, reaches median line and crosses antiporal border of testis. Fully-evaginated cirrus 115-129 long; basal part of cirrus with dilatation, about 10 in diameter, then a little slender part with diameter 5-6, and fusiform median part up to 8-10 (with spines). Distal part of cirrus up to 62 in length, unarmed. Female system with trilobed ovary, in poral part of median field. Vitellarium compact, oval, antiporal to ovary, at level of testis, ventral to it. Uterus sacciform. Gravid eggs 45-49 in diameter. Embryophore rounded, 25-26 in diameter, wall smooth 4-6 in thickness, without polar thickenings. Oncosphere 16-16.5 in diameter. Embryonic hooks of central and lateral pairs identical in shape and length, 10 long.

\section{Remarks}

Yamaguti (1935) described $M$. dujardini in $T$. naumanni from Japan but did not present any illustrations. He mentioned that his material was identical to Fuhrmann's 1895 description. The differences were only in the shape of the ovary, described as lobed by Yamaguti (1935). Data on metrical and meristic characters of specimen described by him and our data of specimens in the same host from Chukotka and in $M$. alba from Paramushir Island coincide. Measurements of $M$. dujardini as reported by various authors and observations from the present study are summarized in Table 1.

\section{Monorcholepis dujardini neoarctica Webster, 1955} [=Monorcholepis dujardini (Krabbe, 1869)]

Redescription. Based on the type material (holotype and paratypes) (Figs. 24-27).

Length of strobila about $2 \mathrm{~mm}$, maximum width 0.16 $\mathrm{mm}$ in holotype. Scolex $164 \times 139$, rostellar sheath saclike, 106 at the level of rostellum. Rostellum $60 \times 86$, number of hooks 42. Proglottides juvenile, without genital organs. Scolex of paratypes 266-272 × 240-262. Rostellum $98 \times 86-131$. Rostellar sheath 170-246 long and 110-160 wide. Rostellar hooks 42-53, of aplo- paraksoid shape; blade as long as guard. Length of hooks 17-18 (blade 9-10, base 15-16, guard 5-7). Neck 127 wide immediately posterior to scolex. Genital atrium dextral, opens in middle of lateral proglottis margin or slightly anterior. Ventral osmoregulatory canals with transverse anastomoses (not always distinct). Male system with oval testis, slightly antiporal, $80 \times$ 60-80. Cirrus-sac 123-213 × 17-21, its antiporal region reaches antiporal osmoregulatory canals. Internal seminal vesicle 103 long, occupies 2/3 of cirrus-sac length. External seminal vesicle rounded, opposite to antiporal region of cirrus-sac, crossing antiporal osmoregulatory canals. Evaginated cirrus (Fig. 29) 109 long. Basal part of cirrus slightly dilated, 10 in diameter; in distal direction, diameter narrows to 7 and then expands to 8 in middle of median fusiform part. Basal swelling and middle part of cirrus armed with small spines arranged in diagonal rows. Distal part of cirrus about 20 long, smooth. Female system with trilobed ovary, in centre of median field. Vitellarium rounded, compact, antiporal to ovary, ventral to testis. Seminal receptacle oval, 25 long and 30 wide, in poral half of median field. Vagina tubular, 85 long and 3 wide.

\section{Remarks}

Webster (1955) believed that this subspecies differed from the nominotypical $A$. dujardini dujardini (Krabbe, 1869) described by Fuhrmann (1895) and Yamaguti (1935) by the following characters: the cirrus-sac is smaller, both absolutely and relative to the proglottis width, the rostellar hooks are slightly longer and the body size is smaller. However, our study showed that specimens of Webster's are very young. The length of hooks is $17-18$ (i.e. the same as described by Krabbe 1869), the cirrus sac (Fig. 26) is long and reaches to the antiporal osmoregulatory canals. Therefore, there are no reasons to place it to the separate subspecies because it corresponds well with the characters of $M$. dujardini (see Table 1).

In the description of Taenia dujardini (syn. Monorcholepis dujardini), Krabbe (1869) summarized data on specimens in Turdus musicus (syn. T. iliacus) from two localities on the coast of the Baltic Sea, Pomerania and Schleswig. These specimens differed by the number and shape of the rostellar hooks. The specimen from Pomerania was $15 \mathrm{~mm}$ long and $1 \mathrm{~mm}$ wide and its rostellum was armed with 40 hooks 16-18 long. The hooks (as shown in Fig. 28) have a short blade (as long as the guard); the cirrus was short, 63 long and 4 wide, cylindrical; and embryonic hooks were 10 long. The total length of the specimen from Schleswig was not noted; its rostellar hooks were the same length (17), but the number of the hooks was 46 and their shape was somewhat different, with a blade slender and shorter than the guard (Fig. 29); the cirrus was slightly longer (88), but twice thicker (8) than in the specimen from Pomerania; the embryophore was round, thick-walled. In spite of the fact that the subsequent descriptions of $M$. dujardini 


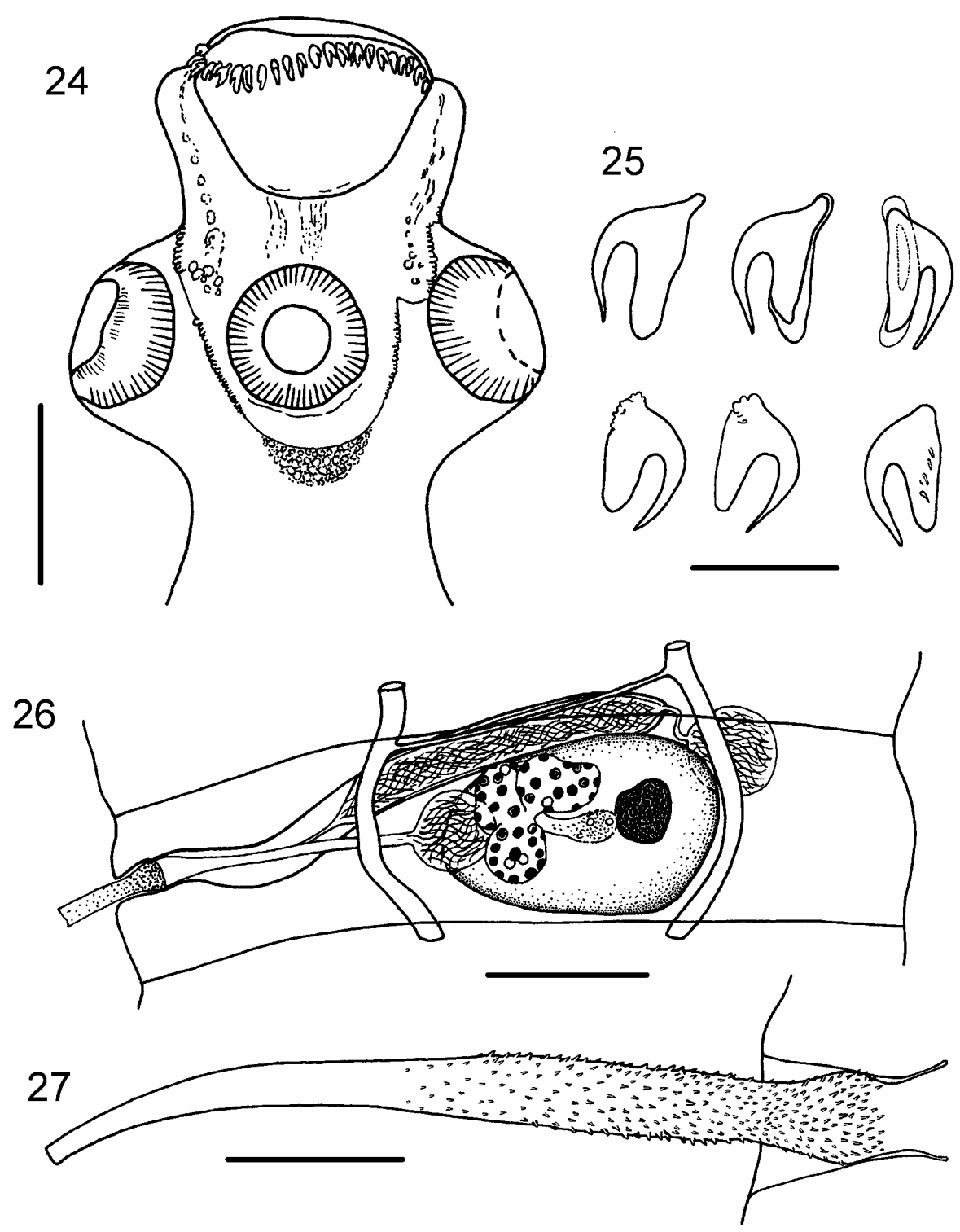

Figs. 24-27. Monorcholepis dujardini (= M. dujardini neoarctica; paratype, USNPC 46648) in Ixoreus naevius from Alaska. Fig. 24. Scolex. Fig. 25. Hooks. Fig. 26. Mature proglottis. Fig. 27. Cirrus. Scale bars: Fig. $24=100 \mu \mathrm{m}$; Figs. $25,27=20 \mu \mathrm{m}$; Fig. $26=50 \mu \mathrm{m}$.

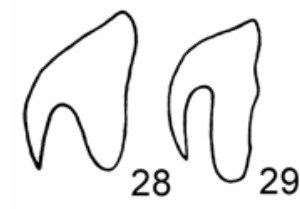

Figs. 28, 29. Rostellar hooks of Monorcholepis dujardini redrawn from Krabbe (1869). Fig. 28. Hook of specimen in Turdus iliacus from Pomerania. Fig. 29. Hook of specimen in T. iliacus from Schleswig. Scale bar $=20 \mu \mathrm{m}$.

by Fuhrmann (1895) and Yamaguti (1935) were more detailed, they did not contain data about rostellar hooks except for their length. In the majority of later publications (Fuhrmann 1932, Joyeux and Baer 1936, Skrjabin and Matevossian 1945, Spasskaya 1966), descriptions of
M. dujardini were shown with illustrations of hooks of specimens from Pomerania and Schleswig redrawn from Krabbe (1869).

The morphology of the specimens in T. naumanni (Chukotka) and M. alba (Paramushir Island) corresponds with specimens described by Yamaguti (1935). On the basis of the present results, we can assume that the number of the hooks of the specimens from European populations of definitive hosts ranges between 40 and 52, from Eastern populations between 46 and 51, and from the North American population between 42 and 53. Demshin (1975) described metacestodes of $M$. dujardini in naturally infected oligochaetes from Primorskiy Kray (Russian Far East) with 46-62 rostellar hooks, 22 long; however, he illustrated a single row consisting of less than 30 hooks. 


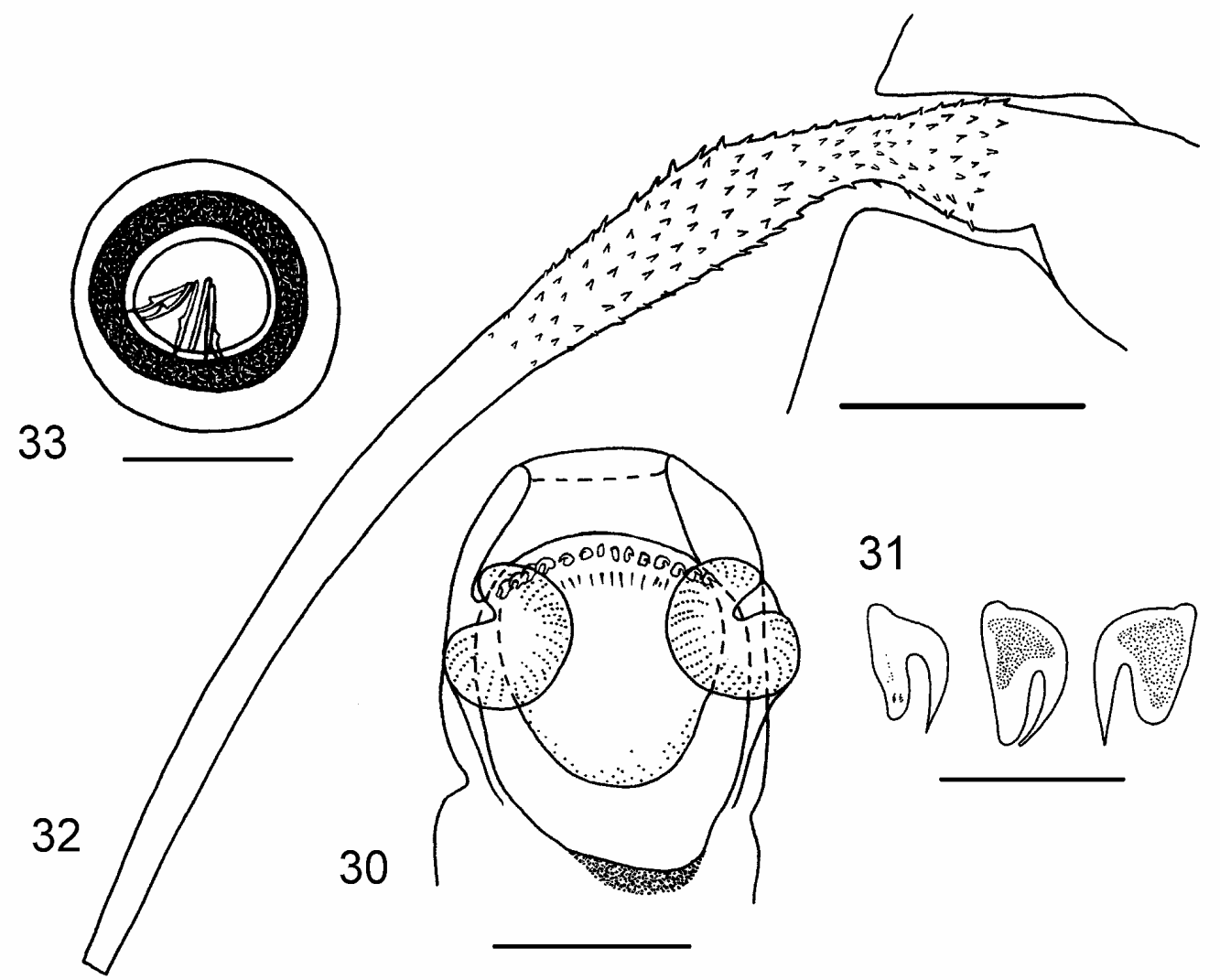

Figs. 30-33. Monorcholepis passerellae (Webster, 1952) in Passerella iliaca iliaca from Point Barrow, Alaska. Fig. 30. Scolex. Fig. 31. Hooks. Fig. 32. Cirrus. Fig. 33. Egg. Scale bars: Fig. $30=100 \mu \mathrm{m}$; Figs. $31,32=20 \mu \mathrm{m}$; Fig. $33=50 \mu \mathrm{m}$.

The shape of the hooks among the $M$. dujardini specimens studied by us varies considerably, especially the hook-base (see Figs. 5, 9-17, 21, 25, 28 and 29). It can be distinct and relatively narrow, or wide, with indistinct boundaries. Probably these conditions can be explained by different stages of development. In mature specimens, the hooks are more dense and stable than in juvenile specimens. Juvenile hooks could be slightly squashed under the cover glass and may undergo changes in form. Nevertheless, we ascribe differences in the shape of hooks to the range of the intraspecific variability of M. dujardini.

Comparison of specimens from different geographical regions shows that there are no substantial differences in strobilar morphology among European, Eastern and North American populations of M. dujardini. However, we are not sure whether the specimen described by Krabbe from Pomerania is conspecific with that found in Schleswig. In Chukotka, two species of this genus have been observed - one with 46 rostellar hooks $(M$. dujardini) and other with 40 (M. atrashkevichi), which differs in the form and size of the cirrus. It is possible that Krabbe had different species too, but the question remains open due to the absence of type slides.
Monorcholepis passerellae (Webster, 1952) Spassky, 1963

Syn.: Aploparaksis passerellae Webster, 1952

Redescription. Based on the type specimen in Passerella iliaca iliaca, and two specimens in P. iliaca from Point Barrow, Alaska collected by R.L. Rausch (Figs. 30-33).

Strobila $24-40 \mathrm{~mm}$ long, with a maximum width of $0.8-0.9 \mathrm{~mm}$. Longitudinal muscles in two distinct layers, inner consisting of 24-40 large bundles (half dorsal and half ventral), outer of numerous small bundles. Scolex 184-258 long and 160-164 wide. Suckers round, 65-74 in diameter, with depth 49-53. Rostellum rounded, 106-109 in diameter. Rostellar sheath 205 long and 127 wide. Rostellar hooks 29 and 31 in number, situated in single row. Hooks with massive base and slightly curved blade almost as long as guard. Length of hooks 14-18 (blade 8-8.5, base 12-15, guard 6-7). Neck $1.75 \mathrm{~mm}$ long, 157-268 wide. Genital pores unilateral, dextral; genital ducts dorsal to longitudinal excretory canals. Ventral canals $28-57$ wide, with rare anastomoses, dorsal canals 5 wide. Male system with antiporal testis, 77-102 long and 188-217 wide. Vas 

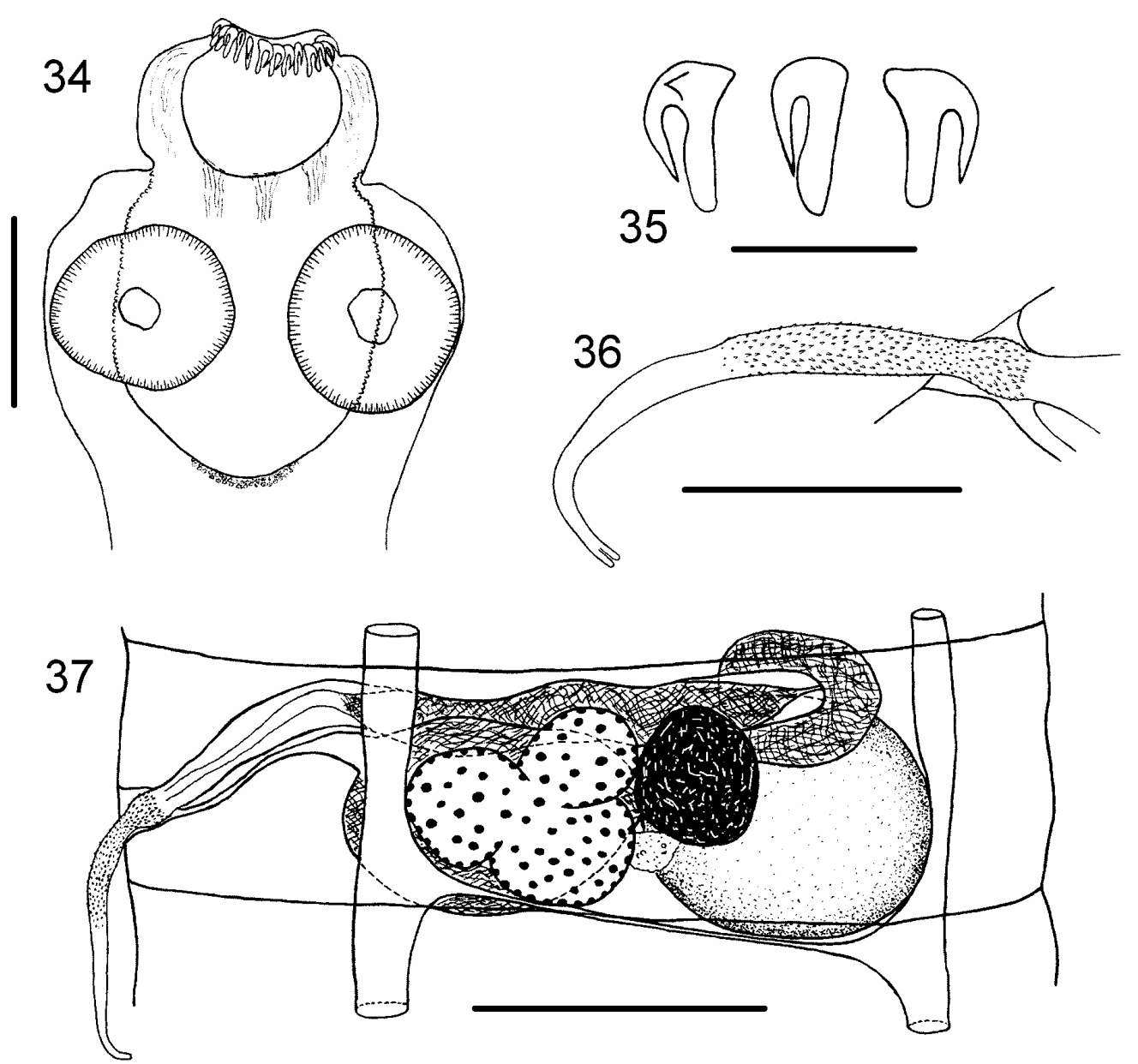

Figs. 34-37. Monorcholepis passerellae in Turdus iliacus, (present study, Curonian Spit) (MHNG INVE 47855, C126/85). Fig. 34. Scolex. Fig. 35. Hooks. Fig. 36. Cirrus. Fig. 37. Mature proglottis. Scale bars: Figs. $34,37=100 \mu \mathrm{m}$; Fig. $35=20 \mu \mathrm{m}$; Fig. $36=50 \mu \mathrm{m}$.

deferens slender, leading from testis to large, ovoid, medially-placed external seminal vesicle. Cirrus-sac 190-287 × 30-45, reaching almost to midline of proglottis. Internal seminal vesicle occupies $2 / 3$ of cirrussac. Cirrus up to 128 long. At basal part, cirrus with dilatation, 8-9 in diameter, then slightly slender part with diameter 5 and fusiform median part with same diameter as base. Proximal part of cirrus covered with tiny spines (spinous part 50 long). Female system with trilobed ovary. Vitellarium oval, 60 in diameter, antiporal to ovarium and ventral to testis. Oval seminal receptacle 30-40 wide, situated antero-poral to median line. Vagina tube-shaped, opens anterior to cirrus-sac. Uterus sac-like, entirely filling all proglottis. Eggs rounded, 42-50 × 63. Embryophore 26-34 × 24-31, with thick smooth walls (thickness 4-6), without polar thickenings. Oncosphere 17-21 × 21-23. Embryonic hooks 12-12.5 long.

- Description of the specimen in Turdus iliacus from the Curonian Spit

Figs. 34-37

Strobila $25 \mathrm{~mm}$ long, with a maximum width of 320 . Scolex, $260 \times 210$. Suckers rounded, 86-90 in diameter. Rostellum rounded, 78 in diameter. Rostellar sheath 217 $\times$ 140. Rostellar hooks 31 in number, situated in single row. Hooks with weakly curved blade, slightly shorter than guard. Length of hooks 18.2 (blade 8.3, base18.2, guard 11.6-12). Neck 900 long. Genital atrium dextral, opens in middle of lateral proglottis margin. Genital ducts pass dorsally across poral longitudinal osmoregulatory canals. Ventral osmoregulatory canals 18-28 wide, with rare transverse canals, dorsal osmoregulatory canals 4 wide, without anastomoses. Male system with antiporal testis, 94-120 long $\times$ 75-92 wide. Vas deferens slender, leading from testis to large, ovoid, medially-placed external seminal vesicle. Cirrus-sac 205-217 $\times 16-21$, reaches and crosses median line of proglottis. Internal seminal vesicle occupies $2 / 3$ of cirrus-sac. Cirrus 78-98 long. At basal part, cirrus with dilatation 10 11.6 in diameter, then little slender part with diameter5.6-6.6 and fusiform median part 7.4-8.3 in diameter. Proximal part of cirrus covered with fine spines. Female system with trilobed ovary. Vitellarium oval, $33-53 \times 29-41$, antiporal to ovarium. Vagina tubular. Oval seminal receptacle $70-98 \times 66-102$, situated poral to median line. The specimen is not gravid; therefore, structure of uterus and eggs was not studied. 
Table 2. Metrical and meristic characters of Monorcholepis passerellae (Webster, 1952).

\begin{tabular}{|c|c|c|c|c|}
\hline Host & Passerella iliaca & Passerella iliaca & Passerella iliaca & Turdus iliacus \\
\hline Locality & $\begin{array}{l}\text { North America } \\
\text { (Madison) }\end{array}$ & $\begin{array}{l}\text { North America } \\
\text { (Madison) }\end{array}$ & $\begin{array}{l}\text { North America } \\
\text { (Point Barrow, Alaska) }\end{array}$ & $\begin{array}{l}\text { Curonian Spit } \\
\text { (Baltic Sea) }\end{array}$ \\
\hline $\mathrm{n}$ & 2 & 1 & 2 & 1 \\
\hline Source & Webster 1952 & Present study* & Present study & Present study \\
\hline Total length (mm) & 24 & 22 & 40 & 25 \\
\hline Maximum width (mm) & 0.80 & 0.74 & 0.88 & 0.32 \\
\hline Scolex: size & $? \times 140-160$ & $? \times 160$ & $258 \times 164$ & $260 \times 210$ \\
\hline Rostellum: size & 109 & - & $106 \times 106$ & $82 \times 78$ \\
\hline Rostellar sheath: size & - & 111 & $205 \times 127$ & $217 \times 140$ \\
\hline \multicolumn{5}{|l|}{ Rostellar hooks: } \\
\hline number & 25 & $25-30 ?$ & $29-31$ & 31 \\
\hline total length & 13 & - & $14-18$ & 18.2 \\
\hline length of blade & & & $8-8.5$ & 8.3 \\
\hline length of base & & & $12-14.9$ & 18.2 \\
\hline guard & & & $6.6-7$ & 11.6-12 \\
\hline Cirrus-sac: size & $190-220$ & $300 \times 33$ & $190-287 \times 30-45$ & $205-217 \times 16-21$ \\
\hline \multicolumn{5}{|l|}{ Cirrus: } \\
\hline shape & - & - & spindle-shaped & spindle-shaped \\
\hline total length & - & - & $109-128$ & $78-98$ \\
\hline base width & - & - & $8-9$ & $10-11.6$ \\
\hline constriction width & - & - & $5-6$ & $5.6-6.6$ \\
\hline median part width & - & - & 8-9 & $7.4-8.3$ \\
\hline Vitellarium: position & - & - & antiporal & antiporal \\
\hline \multicolumn{5}{|l|}{ Embryophore: } \\
\hline size & $24-26 \times 26-30$ & $29 \times 32$ & $26-34 \times 24-31$ & - \\
\hline wall thickness & - & - & $4-6$ & - \\
\hline oncosphere size & $17-21 \times 19-24$ & $21 \times 21$ & $17-21 \times 21-23$ & - \\
\hline embryonic hook length & - & 12 & $12-12.5$ & - \\
\hline
\end{tabular}

*Re-study of the type specimen; measurements in $\mu \mathrm{m}$ unless otherwise stated.

\section{Remarks}

Webster (1952) based his description upon two specimens, one complete (deposited in USNPC as No. 37365 ) and one sectioned. The morphology of the strobila was reconstructed from serial sections. The rostellar hooks were described as 25 in number, 13 long; their illustration was a free-hand sketch. The cirrus was described as stout and unarmed. No data on the ovary were presented. Webster (1952) differentiated $M$. passerellae from $A$. dujardini by the number and the size of the rostellar hooks only.

The re-examination of the holotype of $M$. passerellae was not very useful from the morphological point of view because of its poor condition. Determination of a precise number of hooks in the holotype was not possible, however, it was seen that no more than 30 are present. The two specimens from Alaska provided additional data about the characters not described in the original description. Our specimens had 29 and 31 rostellar hooks (instead of 25 in the original description). The length of the hooks was 14-18 (instead of 13) and their shape (Fig. 31) varied in relation to their position in crown. The comparison between $M$. dujardini (Figs. 19-21) and M. passerellae (Figs. 30-33) from the same bird confirms the validity of the latter species. The species differ by the number and the length of the rostellar hooks: $50-51$ hooks with the length of $18-25$ in $M$. dujardini and 29-31 hooks with the length of 14-18 in $M$. passerellae. The shape of the hooks is also slightly dif- ferent (compare Figs. 17 and 31). Additionally, specimens in T. iliacus collected on the Curonian Spit (Figs. 34-37) are similar to those of $M$. passerellae, based on the number of rostellar hooks (Table 2), but differ by their shape, i.e. the guard is slightly longer than the blade.

\section{DISCUSSION}

The genus Monorcholepis has been characterized by the number of rostellar hooks, which is always higher than 10 , the presence of a single testis and the antiporal position of the vitellarium in relation to the ovary (Oshmarin 1963). When this genus was erected by Oshmarin, other species of Aploparaksis with ten rostellar hooks and the same topography of the gonads were unknown. Spassky and Jurpalova (1968) erected the subgenus Tanureria when they described A. (Tanureria) lateralis. The following diagnosis for the subgenus was provided: "Aploparaksis. Vitellarium compact, antiporal to ovary. Cirrus cylindrical with small basal swelling. Type species - A. (Tanureria) secessivus Gubanov et Mamaev in Spassky, 1963.”

According to Bondarenko and Kontrimavichus (2006), eight species of Aploparaksis correspond to the diagnosis of this subgenus. These are: A. (Tanureria) secessivus, A. (Tanureria) borealis Bondarenko et Rausch, 1977, A. (Tanureria) diagonalis Spassky et Bobova, 1961, A. (Tanureria) galli Rausch, 1951, A. 
(Tanureria) lateralis Spassky et Yurpalova, 1968, A. (Tanureria) pseudosecessivus Belopolskaja, 1969, A. (Tanureria) vanelli Kornyushin, Bondarenko et Greben, 2006 and A. (Tanureria) regelae Bondarenko et Kontrimavichus (2006).

The genera Aploparaksis and Monorcholepis are considered as members of the subfamily Aploparaksinae Mayhew, 1925 (Hymenolepididae) (Spassky and Spasskaya 1972). However, Spassky (1992) elevated Aploparaksinae Mayhew, 1925 to the family rank. Bondarenko and Kontrimavichus (2006) supported this opinion, based on characters of the life cycles of these cestodes. In contrast to hymenolepidid tapeworms, intermediate hosts of aploparaksids are annelids. Moreover, six unique morphological modifications of cysticercoid (not observed among hymenolepidids) are recognized.

The new data on the morphology of $M$. dujardini from various parts of the Holarctic (Table 1) show significant differences in the number, length and shape of the hooks, but the morphology of proglottides in the both species is identical, first of all the shape and length of the cirrus. The variability of the number of the rostellar hooks in M. passerellae is lower than that of $M$. $d u$ jardini, probably because of the small number of specimens available. There is a substantial difference between the number of the hooks of the two species, 2531 and 40-53. However, a range of the number of rostellar hooks between 25 and 53 (or even 62, as described by Demshin, 1975) is considerably beyond the limits of intraspecific variability as recognized among any species of hymenolepidoidean cestodes (see Skryabin and Mathevossian 1945, Spasskaya 1966).

Additional support for the validity of $M$. passerellae and $M$. dujardini is related to the data by Bondarenko and Kontrimavichus (2006) concerning variability in the number and form of hooks observed between two other species, M. sobolevi and M. atrashkevichi, in passerine birds from Chukotka. As mentioned above, these two species differ in the number of rostellar hooks, 20 and 40 , respectively. No specimen with an intermediate number of hooks was found either from naturally infected definitive hosts or from experimentally infected intermediate hosts (Enchytraeidae). However, Aploparaksis (Tanureria) borealis, M. sobolevi and $M$. atrashkevichi can be found in the intestine of the same passeriform bird. They differ mainly in the number of rostellar hooks (10, 20 and 40, respectively). This could be interpreted as a mode of speciation associated with the increase in the number of fixation organs. In $M$. sobolevi and M. atrashkevichi, the hooks may appear to be arranged in pairs on the rostellum; the cirrus is similar in having a cylindrical form and is of moderate dimensions.

Spassky and Spasskaya (1972) mentioned the intermediate morphological position for species of the subgenus Tanureria relative to those of Aploparaksis and
Monorcholepis. They questioned the validity of Monorcholepis and discussed its possible position as a subgenus of Aploparaksis. Bondarenko and Kontrimavichus (2002) returned to this question in the discussion of some unresolved taxonomic problems of the Aploparaksidae. Tanureria and Monorcholepis share similarities in morphological characters (similar topography of gonads in adult tapeworms) and ontogeny of metacestodes (Bondarenko and Kontrimavichus 2002, 2006).

Life cycles and post-embryonal development of four species of Tanureria and three species of Monorcholepis were studied under natural and experimental conditions in the northern regions of Eastern Siberia; annelids were determined to be the intermediate hosts (Bondarenko and Kontrimavichus 2002, 2004, 2006). Patterns of metacestode development and the morphology of mature cysticercoids among Tanureria and Monorcholepis indicate the presence of a unique morphological modification termed an "autotomicercus", which is absent among species of the nominal subgenus Aploparaksis. Species of the latter subgroup are further differentiated by five attributes that are unique among the Aploparaksidae (Bondarenko and Kontrimavichus 1976, 2002, 2006). The development of an autotomicercus is accompanied by formation of a very large primary lacuna. Separated fragments of the tail of the mature autotomicercus can exist independently in the coelom of intermediate hosts for extended periods (several months). Similar metacestodes identified as belonging to $M$. dujardini have also been found in naturally infected oligochaetes from England (Harper 1930) and from Primorskiy Kray (Demshin 1975).

Bondarenko and Kontrimavichus (2006) mentioned, however, that the data on the morphological characters, life cycles and development in the final host are not currently sufficient for proposing an explicit hypothesis about the phylogenetic relations between the species with an antiporal position of the vitellarium and the other Aploparaksidae. Perhaps, results of comparative molecular studies of A. (Tanureria) spp. and Monorcholepis spp. will help resolve this problem in the future.

Acknowledgements. Thanks are due to the following colleagues for providing material for this study: Claude Vaucher, Muséum d'Histoire Naturelle, Geneva; Eric Hoberg and Patricia Pilitt, United States National Parasite Collection, Beltsville, Maryland, USA. We are grateful to Prof. R. Rausch and our colleagues from the Far East State University (FESU) - Prof. O.I. Belogurov and A.K. Tsimbalyuk, Vladivostok, Russia. The help with fieldwork provided by colleagues at the Biological Station of the Zoological Institute, Russian Academy of Sciences is also acknowledged. We are grateful to Boyko B. Georgiev, Eric Hoberg and two anonymous referees for making some useful comments and for help with the language. This work was completed with the financial support of the International Science Foundation (grant LE 3000) and the Lithuanian State Science and Studies Foundation (grant No. C-06/2004(1)). 


\section{REFERENCES}

BondarenKo S.K., Kontrimavichus V.L. 1976: Polymorphism of larvae of the genus Aploparaksis Clerc, 1903 (Hymenolepididae). Folia Parasitol. 23: 39-44.

BONDARENKO S.K., KonTRIMAVICHUS V.L. 1979: [Life cycle and post-embryonic development of Aploparaksis (Tanureria) diagonalis Spassky \& Jurpalova, 1968 - parasite of Charadriiformes.] In: M.D. Sonin (Ed.), [Ecology and Morphology of Helminths of Vertebrates of Chukotka.] Nauka, Moscow, pp. 29-37. (In Russian.)

BondARENKo S.K., KONTRIMAVICHUS V.L. 2002: Cestodes of the genus Aploparaksis Clerc, 1903 (Hymenolepididae): results of research and unsolved issues. In: A.F. Alimov (Ed.), Problems of Cestodology. Vol. 2. Zoological Institute, Russian Academy of Sciences, St. Petersburg, pp. 47-63. (In Russian.)

BONDARENKO S.K., KONTRIMAVICHUS V.L. 2006: Aploparaksidae of Wild and Domesticated Birds. Fundamentals of Cestodology. Vol. 14. Nauka, Moscow, 443 pp.

BONDARENKO S.K., RAUSCH R.L. 1977: Aploparaksis borealis sp. n. (Cestoda: Hymenolepididae) from passeriform and charadriiform birds in Chukotka and Alaska. J. Parasitol. 63: 9698.

CleRC W. 1903: Contribution a l'etude de la faune helminthologique de l'Oural. Rev. Suisse Zool. 11: 241-368.

DEMSHIN N.I. 1975: Oligochaeta and Hirudinea as Intermediate Hosts of Helminths. Nauka, Novosibirsk, 189 pp. (In Rusian.)

FuHRMANN O. 1895: Beitrag zur Kenntnis der Vögeltaenien. I. Rev. Suisse Zool. 4: 433-458.

FuHRMANN O. 1932: Les tenias des Oiseaux. Memoires de l'Université de Neuchâtel. 8: 383 pp.

HAPPER W.F. 1930: On some British larval cestodes from land and fresh-water invertebrate hosts. Parasitology 22: 202-213.

JoYeuX C., BAER J.G. 1936: Faune de France. 30. Cestodes. Office Central de Faunistique, Paris, 613 pp.

KrabBE H. 1869: Bidrag til Kundskab om Fuglenes Baendelorme. Dansk. Vid. Selsk. Skr., Natur. Mat. Afd. 8: 249363.

OSHMARIN P.G. 1963: [Parasitic worms of mammals and birds from the Primorskiy Kray.] Nauka, Moscow, 323 pp. (In Russian.)
SKRYABIN K.I., MATEVOSYAN E.M. 1945: Hymenolepididae of birds. Sel'chozgiz, Moscow, 479 pp. (In Russian.)

SPASSKAYA L.P. 1966: [Hymenolepididae of birds of the USSR.] Nauka, Moscow, 698 pp. (In Russian.)

SPASSKY A.A. 1963: [Hymenolepidids - helminths of wild and domesticated birds.] Part 1. Osnovy Tcestodologii, Vol. 2. Nauka, Moscow, 418 pp. (In Russian.)

SPASSKY A.A. 1992: Two new tribes and the structure of superfamily Hymenolepidea (Cestoda: Cyclophyllidea). Helminthologia 29: 167-170.

SPASSKY A.A., FREZE V.I. 1961: [Review of the genus Aploparaksis Clerc, 1903 (Cestoda: Hymenolepididae).] Československá parasitologie 8: 385-389. (In Russian.)

SPASSKY A.A., SPASSKAYA L.P. 1972: [Genera Monorcholepis Oshmarin, 1961, Chimaerolepis, gen. n., and subfamily Aploparaksinae (Cestoda: Hymenolepididae).] Parazity zhivotnykh i rasteniy, Kishinev, 8: 69-75. (In Russian.)

SPASSKY A.A., YURPALOVA N.M. 1968: [Aploparaksis lateralis, n.sp. (Cestoda; Hymenolepididae) - new species from shorebirds - and substantiation a subgenus Tanureria, n. subgen.] Parazity zhivotnykh i rasteniy, Kishinev, 3: 30-37. (In Russian.)

STEEDMANN H.F. 1958: Dimethyl hydantoin formaldehyde: a new water-soluble resin for use as a mounting medium. Quart. J. Microsc. Sci. 99: 451-452.

TSIMBALYUK A.K., ANDRONOVA K.Y., KULIKOV V.V. 1968: [Monorcholepis sobolevi sp. nov. (Hymenolepididae) and Similuncinus leonovi sp. nov. (Choanotaeniidae) - two new species from the bird of islands of the Bering Sea.] Soobscheniya Dal'nevostochnogo filiala AN SSSR. Helminths of Far East and Pacific ocean, Vladivostok, 26: 126-131. (In Russian.)

WEBSTER J.D. 1952: A new hymenolepidid tapeworm from the fox sparrow. Proc. Indiana Acad. Sci. 61: 305-307.

WEBSTER J.D. 1955: Three new forms of Aploparaksis (Cestoda: Hymenolepididae). Trans. Am. Microsc. Soc. 74: 45-51.

WILLIAMSON F.S., RAUSCH R.L. 1965: Studies on the helminth fauna of Alaska. 62. Aploparaksis turdi sp. n., a hymenolepidid cestode from thrushes. J. Parasitol. 51: 249-252.

YAMAGUTI S. 1935: Studies on the helminth fauna of Japan. Part 6. Cestodes of birds. I. Jpn. J. Zool. 6: 183-232.

Accepted 30 August 2006 